\title{
Pengembangan Lembar Kerja Peserta Didik (LKPD) Berbasis PhET pada Materi Getaran Harmonik
}

\author{
Diva Karunia Safitri*, Imam Sucahyo \\ Program Studi Pendidikan Fisika FMIPA, Universitas Negeri Surabaya, Indonesia \\ *Email: diva.17030184038@mhs.unesa.ac.id
}

DOI: https://doi.org/10.33369/pendipa.6.1.98-104

\begin{abstract}
The aims of this research was to develop a PhET-based Student Worksheet as an effort to keep the implementation of ahe practicum in learning physics even if only virtually. The development of measured through 3 aspects of feasibility assessment where each aspect has special components in its assessment. In its development, phet simulators used related to harmonic vibrations there are 2 masses and springs related to springs and Pendulum Lab that is related to simple swings. This study involved 24 students from class X MIA SMAN 4 Berau High School. The research design used was One Group Pretest -Posttest Design. Based on the research that has been carried out, the results of validity from Student Worksheet on average is $84 \%$ and based on the criteria of interpretation is very valid, based on the criteria of interpretation is very good and the last is on the aspect of the effectiveness of the obtained results 0.8 where based on the criteria of interpretation was high and $77 \%$ in the criteria effectively.
\end{abstract}

Keywords: Worksheet; PhET; Harmonic Vibration

\begin{abstract}
ABSTRAK
Penelitian ini bertujuan untuk mengembangkan Lembar Kerja Peserta Didik (LKPD) berbasis PhET sebagai upaya tetap terlaksananya praktikum pada pembelajaran fisika walau hanya secara virtual. Pengembangan LKPD yang layak (valid, praktis dan efektif) ini diukur melalui 3 aspek penilaian kelayakan dimana masing-masing aspek memiliki komponen-komponen khusus dalam penilaiannya. Dalam pengembangannya, simulator PhET yang digunakan terkait dengan getaran harmonic ada 2 yaitu Masses and spring yang berkaitan dengan pegas serta Pendulum Lab yang bekaitan dengan ayunan sederhana. Penelitian ini melibatkan 24 peserta didik dari kelas X MIA SMAN 4 Berau. Design penelitian yang digunakan adalah One Group Pretest -Posttest Design. Berdasarkan penelitian yang dilakukan, diperoleh hasil validitas dari LKPD secara rata-rata adalah $84 \%$ dimana bedasarkan kriteria interpretasi adalah sangat valid, lalu pada aspek kepraktisan secara rata-rata adalah $84 \%$ dimana bedasarkan kriteria interpretasi adalah sangat baik dan terakhir adalah pada aspek keefektifan memperoleh hasil 0.8 dimana bedasarkan kriteria interpretasi adalah tinggi dan $77 \%$ dalam kriteria efektif.
\end{abstract}

Kata kunci: LKPD; PhET; Getaran Harmonik

\section{PENDAHULUAN}

Fisika merupakan sebuah ilmu dimana materi dan energy serta interaksinya akan dipelajari. Hal-hal tersebut dipelajari melalui sebuah pengamatan, pemahaman serta prediksi terkait dengan fenomena alam yang terjadi maupun system yang dibuat oleh manusia.

Dalam pembelajaran fisika, laboratorium memiliki sebuah peranan yang sangat aktif dan signifikan karena berperan penting dalam pengembangan konsep dan prinsip-prinsip dalam fisika bagi peserta didik karena peserta didik dituntut untuk mengidentifikasi konsep. Untuk pembelajaran fisika, laboratorium juga memainkan peranan yang sangat penting dan berarti karena berguna untuk mengembangkan konsep dan prinsip-prinsip karena siswa terusmenerus diharuskan mengunakan keterampilannya dalam berpikir tingkat tinggi agar dapat mengidentifikasi konsep tersembunyi, 
mendefinisikan dan menjelaskan hukum dan teori yang mendasarinya (Bajpai, M, 2013).

Kondisi pandemic global covid-19 sedang mendera hampir seluruh negara di dunia dan juga berdampak pada pendidikan di Indonesia. peralih dari pembelajaran luring di sekolah menjadi pembelajaran daring terpaksa harus dilakukan guna mengurangi penyebara virus corona. Kondisi ini jugalah yang mendasari bahwa pengembangan berbagai media pembelajaran berkaitan dengan fisika harus semakin banyak. 69\% guru di wilayah jawa Timur dan Jawa Tengah beranggapan bahwa pelaksanaan praktikum sebagai penunjang proses pembelajaran fisika di kelas sangatlah penting sedangakan sisanya $31 \%$ lainnya beranggapan bahwa pelaksanaan praktikum sebagai penunjang proses pembelajaran fisika di kelas penting sehingga sebagai sarana perwujudan pelaksanaan praktikum yang harus dilaksanakan secara daring, digunakannya fasilitas lain seperti laboratorium virtual (Noor, dkk 2020).

Seiring dengan berkembangnya pendidikan di Indonesia disertai dengan perkembangan teknologi yang semakin maju, inovasi-inovasi dalam hal pendidikan akan semakin banyak dan variatif sesuai dengan teknologi yang berkembang. Salah satu perkembangan pendidikan yang disesuikan dengan teknologi yang juga berkembang adalah tersedianya banyak laboratorium virtual sebagai penunjang dalam proses belajar mengajar.

Laboratorium virtual dapat memandu peserta didik untuk melakukan sebuah eksperimen. Laboratorium juga membantu peserta didik memperoleh pengalaman dalam menyelesaikan permasalahan dan situasi sulit yang mereka hadapi. Laboratorium virtual juga bermanfaat dalam meningkatkan kreativitas verbal serta figural lebih tinggi daripada sebuah model pembelajaran konvensional fisika serta membantu meningkatkan kemampuan peserta didik dalam memecahkan sebuah permasalahan (Gunawan, G 2018).

Dalam pengunaan sebuah laboratorium virtual juga dibutuhkan sebuah panduan yang dapat berupa sebuah Lembar Kerja Peserta Didik atau LKPD. LKPD disebut juga dengan LKS atau Lembar Kerja Siswa yang merupakan sebuah pedoman yang digunakan peserta didik dalam pengembangkan keterampilan serta penyelesaian terhadap sebuah masalah kognitif. LKPD berisikan rangkaian kegiatan yang akan dilakukan peserta didik berdasarkan indikator penilaian yang telah dibuat dan harus dicapai oleh peserta didik (Trianto, 2011).

Dalam penyusunan LKPD, LKPD disusun dengan bantuan laboratorium virtual yaitu PhET. PhET merupakan subuah sarana simulator berbagai percobaan yang terdapat dalam beberapa disiplin ilmu khususnya fisika. Penelitian ini memiliki tujuan untuk Mengembangkan Lembar Kerja Peserta didik (LKPD) yang bersifat layak dan memenuhi 3 aspek yaitu validitas, kepraktisan dan keefektivan. Dalam pengembangannya, simulator PhET yang digunakan terkait dengan getaran harmonik ada 2 yaitu Masses and spring yang sesuai dengan materi pegas serta Pendulum Lab yang sesuai dengan dengan ayunan sederhana.

\section{METODE PENELITIAN}

Pada penelitian ini, metode yang digunakan adalah ADDIE (Analysis, Design, Development, Implementation, Evaluation) serta desain yang digunakan adalah One Group Pretest-Posttest Design. One Group Pretest Posttest Design yang digambarkan dengan pola sebagai berikut

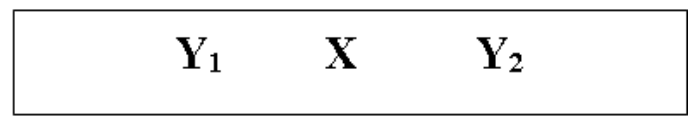

Dengan :

$\mathrm{Y}_{1} \quad=$ Pemberian pretest sebelum dilakukan penerapan pembelajaran menggunakan LKPD yang telah dikembangkan

$\mathrm{X}=$ Penerapan pengembangan LKPD berbasis PhET disertai pembelajaran dengan model PBL pada kelompokkelompok kecil

$\mathrm{Y}_{1}=$ Pemberian posttest setelah dilakukan penerapan pembelajaran menggunakan LKPD yang telah dikembangkan

Subjek penelitian berjumlah 24 peserta didik yang berasal dari kelas X MIA SMA 
Negeri 4 Berau. Penelitian ini dilakukan pada semester genap dimana sesuai dengan waktu penyampaian materi terkait yaitu Gerak Harmonik yang merupakan Kompetensi ke sebelas dalam kompetensi dasar fisika SMA kelas X.

Pengumpulan data serta analisis dalam penelitian ini dibagi sesuai dengan tujuan dalam penelitian ini dan meliputi 3 aspek,yaitu :

1. Validasi

Validasi dalam penelitian ini dilakukan oleh 2 validator yang merupakan ahli dibidangnya, yaitu pembelajaran disekolah dan media pembelajaran. Skala penilaian dalam tahapan validasi adalah menggunakan skala likert empat poin (Four-point Likert Scale) yaitu:

Tabel 1. Skala Likert empat poin

\begin{tabular}{cc}
\hline Penilaian & Skala \\
\hline Sangat Baik & 1 \\
Baik & 2 \\
Kurang Baik & 3 \\
Sangat Kurang & 4 \\
\hline
\end{tabular}

Validasi oleh ahli akan meliputi beberapa komponen yaitu Kebahasaan dengan 3 bagian penilaian, penyajian dengan 4 bagian penilaian dan komponen isi dengan 5 bagian penilaian. Hasil validasi oleh ahli akan di interpretasikan dengan rumus perhitungan dan table berikut ini:

$$
\text { Presentase }=\frac{\text { Skor } \text { Total }}{\text { Skor Maksimum }} \times 100 \%
$$

2. Metode Angket

Kepraktisan dalam penelitin ini akan ditinjau dari angket respon peserta didik yang telah diisi oleh peserta didik ketika telah melalui tahapan-tahapan mulai dari pretest, melaksanakan praktikum secara virtual dengan mengacu pada LKPD yang telah dikembangkan hingga melaksanakan pretest.

Tabel 2. Kriteria Skala Likert (Riduwan,

\begin{tabular}{cc}
\multicolumn{2}{c}{ 2012) } \\
\hline Persentase (\%) & Skala \\
\hline $0-20$ & Sangat Lemah \\
$21-40$ & Lemah \\
$41-60$ & Cukup \\
$61-80$ & Kuat \\
$81-100$ & Sangat Kuat \\
\hline
\end{tabular}

Angket respon peserta didik berisi tentang 8 pertanyaan terkait dengan komponen isi, penyajian serta kebahasaan dari pengembangan LKPD yang telah dikerjakan. Skala penilaian dalam tahapan kepraktisan adalah menggunakan skala likert empat poin (Four-point Likert Scale) yaitu:

Tabel 3. Skala Likert empat poin

\begin{tabular}{cc}
\hline Penilaian & Skala \\
\hline Sangat Baik & 1 \\
Baik & 2 \\
Kurang Baik & 3 \\
Sangat Kurang & 4 \\
\hline
\end{tabular}

Hasil validasi oleh ahli akan di interpretasikan dengan rumus perhitungan dan kriteria interpretasi berikut:

Presentase $=\frac{\text { Skor Total }}{\text { Skor Maksimum }} \times 100 \%$

3. Metode Tes

Keefektian dalam penelitian ini ditinjau dari nilai pesert didik yang diperoleh melalui pretest dan juga posttest. Penilaian pada pretest dan posttest dilakukan berdasarkan rubrik penilaian dengan skala nilai mulai dari 1100. Penghitungan keefektian juga akan 
melibatkan uji N-Gain untuk meninjau bagaimanakah peningkatan hasil belajar antara sebelum pembelajaran dan sesudah pemberlajara. N-Gain dirumuskan dengan:

$$
N-\text { Gain }=\frac{\text { Skor Posttest }- \text { Skor Pretest }}{\text { Skor Maksimum }- \text { Skor Pretest }}
$$

Tabel 4. Kriteria Skala Likert (Riduwan,

\begin{tabular}{cc}
\multicolumn{2}{c}{ 2012) } \\
\hline Persentase (\%) & Skala \\
\hline $0-20$ & Sangat Lemah \\
$21-40$ & Lemah \\
$41-60$ & Cukup \\
$61-80$ & Kuat \\
$81-100$ & Sangat Kuat \\
\hline
\end{tabular}

Hasil perhitungan N-Gain akan diinterpretasikan dalam kriteria Gain Ternomalisasi dan efektivitas N-Gain dalam persentase adalah sebagai berikut ini:

Tabel 5. Kriterian Gain Ternormalisasi (Sundayana, 2014)

\begin{tabular}{cc}
\hline Nilai N-Gain & Interpretasi \\
\hline $0,70 \leq \mathrm{g} \leq 100$ & Tinggi \\
$0,30 \leq \mathrm{g} \leq 0,70$ & Sedang \\
$0,00 \leq \mathrm{g} \leq 0,30$ & Rendah \\
$\mathrm{g}=0,00$ & $\begin{array}{c}\text { Tidak Terjadi } \\
\text { Peningkatan }\end{array}$ \\
$-1,00 \leq \mathrm{g} \leq 0,00$ & Terjadi \\
& Penurunan \\
\hline
\end{tabular}

\section{HASIL DAN PEMBAHASAN}

Penelitian yang telah dilakukan menghasilkan beberapa data sesuai dengan 3 aspek yang dibutuhkan dalam LKPD, yaitu:

1. Validasi
Validasi dilakukan oleh 2 orang ahli dalam bidang pendidikan serta pengembangan media. Terdapat 3 komponen yang dinilai dalam LKPD yang dikembangkan yaitu Kebahasaan, Penyajian dan komponen isi yang disajikan dalam grafik dibawah ini:

Tabel 6. Kriterian Efektivitas N-Gain (Hake, R.R, 1999)

\begin{tabular}{cc}
\hline Persentase(\%) & Interpretasi \\
\hline$<40$ & Tidak Efektif \\
$40-55$ & Kurng Efektif \\
$56-75$ & Cukup Efektif \\
$>76$ & Efektif \\
\hline
\end{tabular}

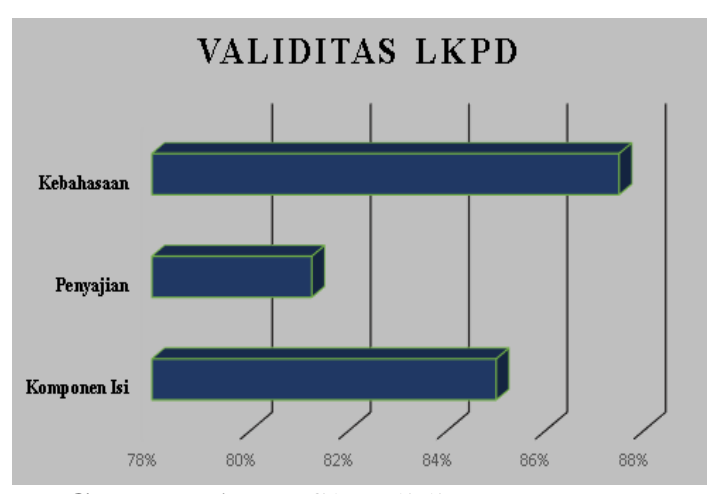

Gambar 1. Grafik validitas LKPD

Berdasarkan data validasi yang telah dinilai oleh validator dan disajikan dalam bentuk grafik batang diatas, diperoleh bahwa kebahasaan menjadi komponen yang memiliki presentase paling besar yaitu $88 \%$. Penilaian yang diberikan terkait dengan kebahasaan adalah pada penggunaan gaya bahasa, pemilihan istilah dan kata yang tepat serta jelas, sehingga berdasarkan hasil tersebut, pengunaan Bahasa dalam penyusunan LKPD ini termasuk dlam kategori sangat kuat atau sama dengan sangat baik.

Komponen selanjutnya adalah penyajian, penyajian memperoleh hasil paling kecil yaitu $81 \%$ dimana kekurangan terdapat pada penggunaan ilustrasi yang dapat menarik minat 
peserta didik dianggap masih kurang dan terdapat dalam kategori baik sehingga harus dikembangkan lebih lanjut menjadi LKPD yang lebih baik lagi.

$$
\text { Komponen validitas yang }
$$
terakhir adalah komponen isi yang memperoleh hasil 85\%. Pada komponen ini penilaian diberikan berdasarkan kesesuaian LKPD dengan Kompetensi Dasar Fisika pada Kurikulum 2013, cakupan terhadap tujuan pembelajaran, kesesuaian dengan indikator dan materi serta kaitan materi dengan kehidupan sehari-hari. Berdasarkan nilai tersebut diketahui bahwa pengembangan LKPD yang dilakukan telah memiliki kesesuain dengan $\mathrm{KD}$, indikator serta tujuan dalam pembelajaran fisika kurikulum 2013.

Rentang nilai validasi LKPD yang diperoleh adalah antara $81 \%$ sampai dengan $88 \%$ dan secara rata-rata adalah $84 \%$ dimana bedasarkan kriteria interpretasi skala likert adalah sangat kuat atau disesuaikan dengan konteks validasi menjadi Sangat Valid.

2. Kepraktisan

Kepraktisan LKPD ditinjau dari hasil pengisian angket oleh peserta didik. Angket respon ini memiliki 8 pertanyaan yang berkaitan dengan kesesuaian komponen-komponen penyusun LKPD. Dibawah ini merupakan graik dari penilaian yang telah dilakukan peserta didik terkait dengan LKPD

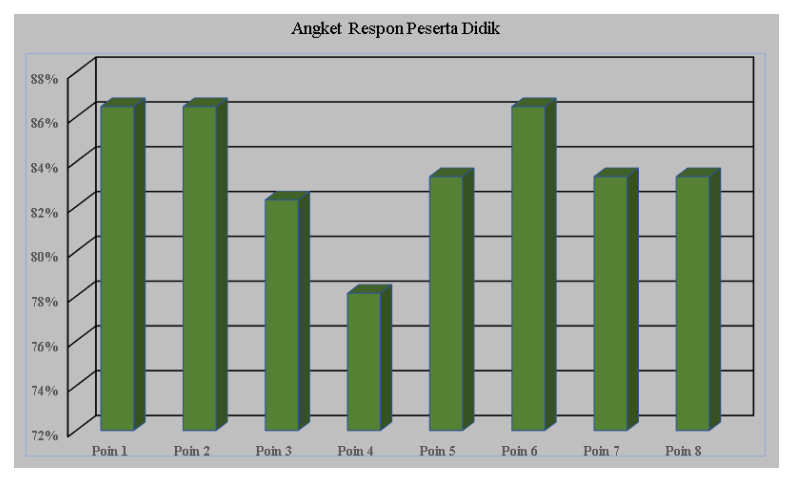

Gambar 2. Grafik angket respon peserta didik terhadap LKPD
Poin-poin pertanyaan terkait LKPD tersebut adalah

1. Apakah tampilan dari LKPD memiliki tampilan yang baik?

2. Apakah LKPD menggunakan bahasa yang baik dan benar?

3. Apakah LKPD sesuai dengan materi pembelajaran?

4. Apakah LKPD membantu dalam memahami materi getaran harmonic?

5. Apakah petunjuk kegiatan di LKPD pada tiap praktikum jelas dan mudah dimengerti?

6. Apakah LKPD menyajikan permasalahan yang sesuai dengan tujuan pembelajaran

7. Apakah LKPD membantu menyelesaikan permadalahan terkait praktikum?

8. Apakah secara keseluruhan LKPD ini sudah baik?

Poin 1 memiliki hasil persentase $86 \%$ yang merupakan kategori sangat baik, poin 2 memiliki hasil $86 \%$ yang merupakan kategori sangat baik, poin 3 memiliki hasil $82 \%$ yang merupakan kategori sangat baik, poin 4 memiliki hasil $78 \%$ yang merupakan kategori baik, poin 5 memiliki hasil $83 \%$ yang merupakan kategori sangat baik, poin 6 memiliki hasil $86 \%$ yang merupakan kategori sangat baik, poin 7 memiliki hasil $83 \%$ yang merupakan kategori sangat baik, poin 8 memiliki hasil $83 \%$ yang merupakan kategori sangat baik.

Penilaian terendah ada pada poin ke-4 dimana pada poin tersebut berisi mengenai apakah LKPD membantu dalam menguasai pemahaman terkait dengan materi getaran harmonik. Hal ini berarti bahwa peserta didik kurang merasakan manfaat LKPD terhadap pemahaman mengenai materi, sehingga sebaiknya LKPD dikembangkan menjadi lebih lengkap lagi.

Dari keseluruhan penilaian yang diperoleh melalui angket respon peserta didik terhadap LKPD, maka rata-rata presentase yang diperoleh adalah $84 \%$ 
atau sudah $>60 \%$ sehingga LKPD ini dinilai sudah sangat baik.

\section{Keefektifan}

Keefektifan LKPD akan ditinjau berdasarkan hasil uji sebelum dan sesudah pelaksanaan pembelajaran menggunakan pengembangan LKPD yang telah dilakukan oleh peserta didik. Hasil uji pada peserta didik tersebut disajikan dalam garfik berikut:

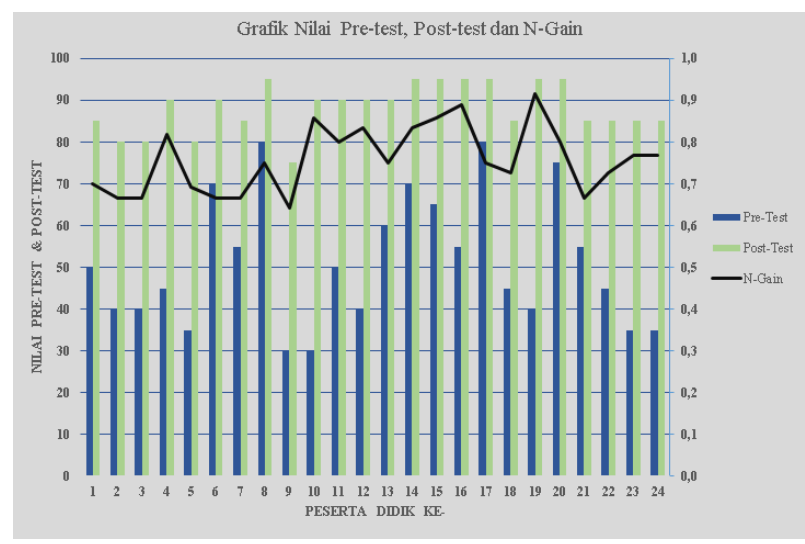

Gambar 3. Grafik pre-test, post-test dan N-Gain oleh Peserta Didik

Grafik batang merepresentasikan mengenai hasil uji sebelum dan sesudah penerapan pembelajaran menggunakan pengembangan LKPD yang telah dilakukan. Seperti yang disajikan pada grafik, ke-24 peserta didik melakukan uji sebelum dan sesudah sehingga kedua nilai itu dapat dibandingkan. Berdasarkan nilai ketuntasan, pada saat uji sebelum penerapan LKPD peserta banyak yang tidak dapat mencapai kriteria ketuntasan minimum yaitu 75 , sedangkan pada uji sesudah penerapan LKPD peserta didik secara keseluruhan mampu mencapai kriteria ketuntasan minimum (KKM) tersebut.

Grafik garis atau line merepresentasikan N-Gain. Perbedaan nilai masing-masing peserta didik akan mempengaruhi nilai N-Gain pada masing-masing peserta didik. Berdasarkan perhitungan N-Gain terhadap hasil uji sebelum dan sesudah pelaksanaan pembelajaran menggunakan pengembangan LKPD ke-24 peserta didik diperoleh rentang $\mathrm{N}$-Gain antara 0,6-0,9 dengan rata-rata adalah 0,8 (Pembulatan keatas) dimana hasil tersebut termasuk dalam kategori tinggi.

Berdasarkan perhitungan N-Gain terhadap hasil uji sebelum dan sesudah pelaksanaan pembelajaran menggunakan pengembangan LKPD 24 peserta didik juga diperoleh nilai efektivitas N-Gain yaitu sebesar $77 \%$ efektif dan $23 \%$ tidak efektif. Berdasarkan kategori efektivitas N-Gain (Hake, R.R, 1999) maka LKPD ini termasuk dalam kategori Efektif penggunaannya dalam proses belajar mengajar.

\section{KESIMPULAN}

Berdasarkan penelitian yang telah dilakukan, dapat disimpulkan bahwa LKPD yang telah dikembangkan layak untuk digunakan sesuai dengan 3 aspek penilaian kelayakan, yaitu validitas, kepraktisan dan keefektivan. Validitas dari LKPD secara rata-rata adalah $84 \%$ dimana bedasarkan kriteria interpretasi adalah sangat valid, lalu pada aspek kepraktisan secara rata-rata adalah $84 \%$ dimana bedasarkan kriteria interpretasi adalah sangat baik dan terakhir adalah pada aspek keefektifan memperoleh hasil 0.8 dimana bedasarkan kriteria interpretasi adalah tinggi dan $77 \%$ dalam kriteria efektif.

\section{DAFTAR PUSTAKA}

Bajpai, M. (2013). Developing concepts in physics through virtual lab experiment: an effectiveness study. Techno Learn, 3(1), 43.

Brown,Sorrel. (2010). Likert Scale Examples for Surveys. Iowa State University

Gunawan, G., Suranti, N. M. Y., Nisrina, N., Herayanti, L., \& Rahmatiah, R. (2018, November). The effect of virtual lab and gender toward students' creativity of physics in senior high school. In Journal of Physics: Conference Series (Vol. 1108, No. 1, p. 012043). IOP Publishing.

Knapp, T. R. (2016). Why is the one-group pretest-posttest design still used? 
Nirmalasari, N., Santiani, S., \& Rohmadi, H. M. (2016). Penerapan model pembelajaran learning cycle terhadap ketrampilan proses sains dan hasil belajar siswa pada pokok bahasan getaran harmonis. EduSains, 4(2), 79-94.

Noor, Yusmaniar Aifah, dkk. (2020). Praksis Praktikum Fisika Mode Daring: Studi Kasus Pembelajaran di SMA/MA Jawa Tengah dan Jawa Timur Semasa Pandemi Covid-19. UPEJ 9(3), 278.

Razi, P. (2013). Hubungan Motivasi Dengan Kerja Ilmiah Siswa Dalam Pembelajaran Fisika Menggunakan Virtual Laboratory Di Kelas X SMAN Kota Padang. Jurnal Teknologi Informasi \& Pendidikan,6(2), 119-124.
Salleh, S. M. H., Jack, S., Bohari, Z., \& Jusoff, H. (2011). Use of Information and Communication Technology in Enhancing Teaching and Learning. International Education Studies, 4(2), 153-156.

Sundayana, Rostina (2014) Statistika Penelitian Pendidikan. Bandung: Alabeta.

Trianto. 2011. Model Pembelajaran Terpadu. Jakarta: Bumi Aksara.

Yusuf, I., Widyaningsih, S. W., \& Purwati, D. (2015). Pengembangan perangkat pembelajaran Fisika Modern berbasis media laboratorium virtual berdasarkan paradigma pembelajaran abad 21 dan Kurikulum 2013. Pancaran 